\title{
PELATIHAN PERHITUNGAN HARGA POKOK BERBASIS EXCEL PADA HOTEL RUMAH PUTIH ABU-ABU
}

\author{
Animah"), Adhitya Bayu Suryantara'1), Widia Astuti1) \\ ${ }^{1)}$ Akuntansi, Fakultas Ekonomi dan Bisnis, Universitas Mataram, Mataram, Nusa Tenggara Barat, Indonesia \\ Corresponding author :Adhitya Bayu Suryantara \\ E-mail :adhityabayus@unram.ac.id
}

Diterima 03 Februari 2021, Direvisi 27 Februari 2021, Disetujui 28 Februari 2021

\begin{abstract}
ABSTRAK
Saat ini dalam semua lini bisnis sudah berbasis aplikasi. Demikian pula halnya untuk bisnis hotel, agar tidak ketinggalan dalam manejemennya perlu penerapan aplikasi terutama dalam laporan keuangan. Selama ini Hotel Rumah Putih Abu-Abu (RPA) menyusun laporan keuangan dengan menggunakan jasa konsultan, meskipun di dalam pencatatan penerimaan kas dan pengeluaran kas di hotel sudah menggunakan excel. Hal ini terjadi karena kurangnya pemahaman manajemen di dalam penyusunan laporan keungan terutama mengenai perhitungan harga pokok kamar. Penetapan tarif kamar hanya berdasarkan pada persaingan pasar dan melihat pada biaya yang dikeluarkan saja. Oleh karena itu tim pengabdian akan melakukan pelatihan mengenai perhitungan harga pokok kamar dengan menggunakan pendekatan full cost berbasis excel. Tujuan dari pengebdian ini untuk memberikan peningkatan soft skill bagi pengelola hotel dalam menghitung biaya-biaya yang muncul disetiap kegiatan bisnisnya secara akurat. Metode yang dilakukan adalah pemberdayaan partisipatif, yang meliputi penyuluhan dan pelatihan, monitoring dan evaluasi dengan sasarannya adalah manajemen dan karyawan hotel yang berjumlah 7 orang.Setelah diberikan penyuluhan dan pelatihan, manajemen Hotel RPA mengakui mereka memiliki kemampuan dan keterampilan yang memadai dalam membuat pencatatan yang digunakan untuk menghitung harga pokok produksi.
\end{abstract}

Kata Kunci: perhitungan; harga pokok; excel

\begin{abstract}
Currently, all business lines are application-based. Likewise for the hotel business, so as not to be left behind in its management, it is necessary to apply applications, especially in financial reports. So far, Rumah Putih Gray Hotel has prepared financial reports using the services of a consultant, although in recording cash receipts and cash disbursements at the hotel have used excel. This occurs due to a lack of understanding by management in preparing financial reports, especially regarding the calculation of the cost of the room. Room rates are determined solely based on market competition and looking at the costs incurred. Therefore the community service team will conduct training on calculating the cost of the room using an excel-based full cost approach. The method used is participatory empowerment, which includes counseling and training, monitoring and evaluation with the target of 7 hotel management and employees. After being given counseling and training, the RPA Hotel management acknowledged that they had sufficient ability and skills to make records that were used to calculate the cost of production.
\end{abstract}

Keywords: calculation; cost of goods; excel

\section{PENDAHULUAN}

Bisnis penyedia jasa yang mengalami persaingan terketat di Indonesia adalah hospitality industry (Hermawan, Bramanto, \& Hamzah, 2018). Hotel merupakan salah satu usaha yang termasuk di dalam hospitality industry memiliki jasa penginapan yang bertujuan untuk memenuhi keinginan pelanggan. Oleh karena itu penerapan tarif inap di hotel sangat dipengaruhi oleh persaingan dan kualitas layanan yang diberikan (Isdarmanto, 2017).
Penentuan tarif kamar hotel yang ditentukan dari kualitas layanan dipengaruhi oleh fasilitas yang melekat pada tipe jasa yang ditawarkan. Fasilitas jasa ini menimbulkan besarnya komponen biaya yang melekat di dalam penentuan harga pokok yang pada akhirnya mempengaruhi tarif kamar (David, llat, \& Morasa, 2020). Semakin banyak fasilitas yang ditawarkan, maka jenis biaya yang timbul akan semakin bervariasi. Hotel harus mampu mengurangi dan mengendalikan biaya, tanpa mengurangi kualitas dan kuantitas produk yang telah ditetapkan. Pengendalian biaya akan 
lebih efektif bila biaya-biaya diklasifikasikan dan dialokasikan dengan tepat (Sujarweni, 2017).

Harga pokok mempunyai peranan yang sangat penting dalam menentukan harga jual produk(Yuniari, Wahyuni, \& Dewi, 2017). Penetapan biaya yang lebih tepat akan menghasilkan harga pokok jasa yang lebih akurat. Oleh karena itu, hotel harus benarbenar serius menangani harga pokok kamarnya. Dalam perhitungan biaya produk untuk menentukan harga pokok produksi/ jasa masih banyak perusahaan yang menggunakan sistem tradisional metode full costing (Mulyadi, 2014).

Berdasarkan hasil survei yang kami laksanakan, hotel rumah putih abu-abu di dalam menghitung harga pokok di dasarkan pengeluaran kas saja misalnya listrik, air dan gaji pegawai tetapi untuk biaya depresiasi, sewa misalnya tidak pernah dibebankan, sehingga dapat kami simpulkan bahwa perhitungan harga pokok kamar yang dilakukan oleh hotel belum sesuai dengan pendekatan full cost, varialel cost maupun activity based costing. Oleh karena itu tim pengabdian kami akan melaksanakan pengabdian mengenai perhitungan harga pokok kamar dengan pendekatan full cost.

Berdasarkan analisis situasi pada latar belakang, beberapa hal yang dianggap sebagai masalah prioritas yang harus ditangani antara lain 1) Pengetahuan tentang biaya tetap dan biaya variable yang dimiliki karyawan hotel rumah putih abu-abu masih terbatas. 2) Pengetahuan yang dimiliki karyawan hotel rumah putih abu-abu dalam menyusun harga pokok hanya melihat beban yang mengeluarkan kas saja. 3)Perhitungan harga pokok kamar belum sesuai standar akuntansi keuangan

\section{METODE}

Pelaksanaaan kegiatan pengabdian ini dilaksanakan selama 4 bulan antara bulan Juni hingga september di hotel rumah putih abu-abu Senteluk Batulayar Lombok barat. Metode yang digunakan untuk memecahkan masalah yang terkait dengan perhitungan harga pokok kamar hotel rumah putih abu-abu adalah :

a. Ceramah dan tanya jawab, untuk menjelaskan komponen harga pokok kamar kepada peserta yaitu semua karyawan rumah putih abu-abu berjumlah 7 orang

b. Demonstrasi untuk menjelaskan suatu penciptaan model perhitungan harga pokok kamar dengan pendekatan full cost berbasis excel. Dengan demikian peserta dapat mengamati secara langsung penyusunan harga pokok kamar dengan menggunakan excel. c. Latihan atau praktik, peserta akan mempraktekkan semua materi yang sudah dijelaskan oleh pelatih. Latihan meliputi: mengidentifikasi biaya tetap dan biaya variable, kemudian mencatat ke dalam sheet yang ada di excel. Berdasarkan data yang sudah dimasukkan ke dalam sheet tadi, kemudian disusunlah harga pokok dengan menggunakan formula atau rumus-rumus yang dapat digunakan di excel.

Indikator keberhasilan dari kegiatan pengabdian ini adalah karyawan mampu mengidentifikasi biaya variabel dan biaya tetap serta mampu menghitung harga pokok dengan mengggunakan pendekatan full cost baik secara manual maupun dengan menggunakan excel.

\section{HASIL DAN PEMBAHASAN}

Untuk mengetahui laba atau rugi secara periodik suatu perusahaan dihitung dengan mengurangkan pendapatan yang diperoleh dengan biaya-biaya yang dikeluarkan untuk memperoleh nilai laba atau rugi tersebut (Kaukab, 2019). Oleh karena itu diperlukan informasi dari harga pokok produksi (Mulyadi, 2014) mengungkapkan harga pokok produksi dalam pembuatan produk terdapat dua kelompok biaya yaitu biaya produksi dan biaya nonproduksi.

Biaya produksi merupakan biaya-biaya yang dikeluarkan dalam pengolahan bahan baku menjadi produk, sedangkan biaya non produksi merupakan biaya biaya yang dikeluarkan untuk kegiatan nonproduksi, seperti kegiatan pemasaran dan kegiatan administrasi umum. Biaya produksi membentuk harga pokok produksi, yang digunakan untuk menghitung harga pokok produk yang pada akhir periode akuntansi masih dalam proses. Biaya non produksi ditambahkan pada harga pokok produksi untuk menghitung total harga pokok produk.

Kegiatan pengabdian kepada masyarakat telah dilakukan sesuai jadwal yang telah ditentukan sesuai dengan kesepakatan dengan mitra pengabdian. Hotel RPA Batulayar Senggigi selama ini tidak membuat perhitungan harga pokok kamar, yang ada hanya membuat laporan keuangan diantaranya rugi-laba dan neraca tetapi tidak terdapat harga pokok kamar, karena standar pelaporan keuangan untuk perusahaan jasa tidak mencantumkan harga pokok kamar, tetapi jika manajemen ingin mengetahui apakah tarif yang dibebankan kepada konsumen terlalu tinggi atau terlalu rendah, maka diperlukan perhitungan harga pokok kamar sebagai dasar dalam menentukan harga jual. 
Oleh karena itu tim pengabdian memberikan penyuluhan mengenai perhitungan harga pokok kamar dengan pendekatan full cost, dengan tujuan perhitungan ini relative lebih mudah sehingga dapat dimanfaatkan oleh mitra. Adapun materi penyuluhan yang dilakukan oleh tim pengabdian meliputi:

1. Menjelaskan komponen biaya tetap dan biaya variabel dalam suatu perusahaan dalam hal ini hotel RPA

2. Mengidentifikasi biaya-biaya (terlihat di gambar 1) yang termasuk biaya variabel misalnya biaya bahan baku terkait dengan breakfast, biaya tenaga kerja langsung yang melayani tamu hotel, biaya listrik, air dsb. Sedangkan biaya tetap biaya depresiasi, biaya tenaga kerja, PBB dsb.

3. Menggolongkan rincian biaya tetap (terlihat di tabel 1) dan rincian biaya variable (terlihat di tabel 2) berdasarkan biaya bahan baku, tenaga kerja, biaya overhead pabrik, biaya pemasaran dan biaya administrasi dan umum. dan yang terakhir komponen biaya overhead variable.

Tabel 1. Rincian Biaya Tetap

\begin{tabular}{|c|c|c|}
\hline Keterangan & $\begin{array}{l}\text { Jenis } \\
\text { Biaya }\end{array}$ & Jumlah \\
\hline $\begin{array}{l}\text { Gaji Manajer } \\
\text { Housekeeping }\end{array}$ & Tetap & $13,800,000$ \\
\hline $\begin{array}{l}\text { Gaji } 3 \text { karyawan } \\
\text { Tetap }\end{array}$ & Tetap & $30,600,000$ \\
\hline Gaji 2 Pemagang & Tetap & $4,680,000$ \\
\hline Indihome & Tetap & $6,695,474$ \\
\hline $\begin{array}{l}\text { Perlengkapan } \\
\text { front office }\end{array}$ & Tetap & $3,801,358$ \\
\hline PBB & Tetap & $1,770,780$ \\
\hline $\begin{array}{l}\text { Depresiasi Interior } \\
\text { \& Furnitur }\end{array}$ & Tetap & $46,500,862$ \\
\hline Depresiasi Bangunan & Tetap & $34,815,447$ \\
\hline $\begin{array}{l}\text { Depresiasi Machine } \\
\text { \& Instalation }\end{array}$ & Tetap & $5,090,431$ \\
\hline Total & & $147,754,352$ \\
\hline
\end{tabular}

Tabel 2. Rincian Biaya Variabel

\begin{tabular}{llc}
\multicolumn{1}{c}{ Keterangan } & $\begin{array}{l}\text { Jenis } \\
\text { Biaya }\end{array}$ & \multicolumn{1}{c}{ Jumlah } \\
\hline Breakfast & Variabel & $23,475,000$ \\
\hline Air galon $(\mathrm{ml})$ & Variabel & 461,700 \\
\hline $\begin{array}{l}\text { kopi nescafe } \\
\text { (sachet }\end{array}$ & Variabel & 279,000 \\
\hline
\end{tabular}

\begin{tabular}{|c|c|c|}
\hline Teh (bks) & Variabel & 200,500 \\
\hline $\begin{array}{l}\text { Indocafé mix } \\
\text { sachet }\end{array}$ & Variabel & 608,000 \\
\hline Pulpy orange (ml) & Variabel & $2,223,000$ \\
\hline Sandal Hotel & Variabel & $3,000,000$ \\
\hline Anti Insect Sprayer & Variabel & 678,300 \\
\hline Room sprayer & Variabel & $1,001,000$ \\
\hline Tissue & Variabel & 281,400 \\
\hline Soap & Variabel & $1,022,000$ \\
\hline Shampoo & Variabel & $1,235,000$ \\
\hline Conditioner & Variabel & 844,200 \\
\hline Toilet Tissue & Variabel & 188,000 \\
\hline Laundry Bag & Variabel & 82,775 \\
\hline Bathroom cleaner & Variabel & 640,000 \\
\hline Glass Cleaner & Variabel & 105,600 \\
\hline $\begin{array}{l}\text { Multipurposes } \\
\text { cleaner }\end{array}$ & Variabel & 322,000 \\
\hline Furniture Polish & Variabel & 198,000 \\
\hline Trash Bag & Variabel & 98,925 \\
\hline Detergent & Variabel & 301,000 \\
\hline Laundry kamar & Variabel & $7,524,000$ \\
\hline Listrik & Variabel & $11,451,087$ \\
\hline PDAM & Variabel & $2,878,800$ \\
\hline Pulsa handphone & Variabel & $1,375,700$ \\
\hline Booking.com & Variabel & $22,426,575$ \\
\hline $\begin{array}{l}\text { Upah Perbaikan } \\
\text { Pools }\end{array}$ & Variabel & 930,000 \\
\hline Pajak hotel & Variabel & $6,809,300$ \\
\hline $\begin{array}{l}\text { Upah Perbaikan } \\
\text { AC }\end{array}$ & Variabel & 375,000 \\
\hline $\begin{array}{l}\text { Upah Perbaikan } \\
\text { Kulkas }\end{array}$ & Variabel & 151,000 \\
\hline $\begin{array}{l}\text { Upah Perbaikan } \\
\text { Mesin Cuci }\end{array}$ & Variabel & 55,000 \\
\hline Cairan Pools & Variabel & $4,355,000$ \\
\hline $\begin{array}{l}\text { Tanaman untuk } \\
\text { taman }\end{array}$ & Variabel & $2,934,000$ \\
\hline
\end{tabular}




\begin{tabular}{lll}
\hline Material Lampu & Variabel & $1,311,000$ \\
\hline Material Pools & Variabel & $5,956,000$ \\
\hline Material Kulkas & Variabel & 346,000 \\
\hline Cat & Variabel & $10,902,500$ \\
\hline Material AC & Variabel & $1,061,500$ \\
\hline Material Garden & Variabel & $\mathbf{9 7 , 0 0 0}$ \\
\hline \multirow{2}{*}{ Total } & & $\mathbf{1 1 8 , 1 8 4 , 8 6}$ \\
\hline
\end{tabular}

4. Berdasarkan hal tersebut, maka tim pengabdian telah membuat format perhitungan harga pokok produksi yang sesuai dengan ilmu akuntansi biaya biaya dengan menggunakan excel. Tim pengabdian telah melakukan: a) Penyampaian materi tentang metode/pendekatan harga pokok produksi. Sasaran pemberian materi ini adalah pemilik usaha (Mitra). Tujuan disampaikannya meteri ini adalah agar pemilik usaha (Mitra) dan manajemen memiliki pengetahuan dan pemahaman tentang perhitungan harga pokok produk dan penyusunan laporan harga pokok produksi sesuai ilmu akuntansi biaya agar dihasilkan informasi biaya produksi yang akurat. ini adalah agar pemilik usaha (Mitra) dan manajemen memiliki pengetahuan dan pemahaman tentang perhitungan harga pokok produk dan penyusunan laporan keuangan.

5. Memberikan pelatihan kepada pihak manajemen dalam membuat catatan akuntansi terutama pencatatan yang digunakan sebagai dasar dalam perhitungan harga pokok produksi seperti yang terlihat di Gambar 2.

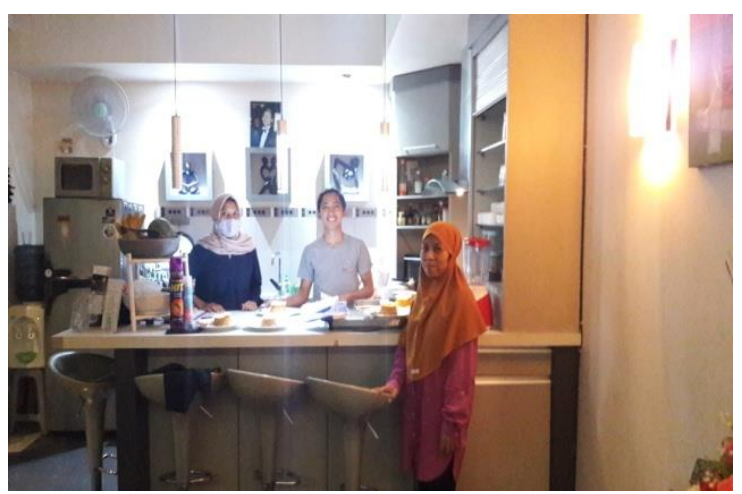

Gambar 1. Salah Satu Kegiatan Identifikasi Biaya Operasional (Sumber: Data Penulis)

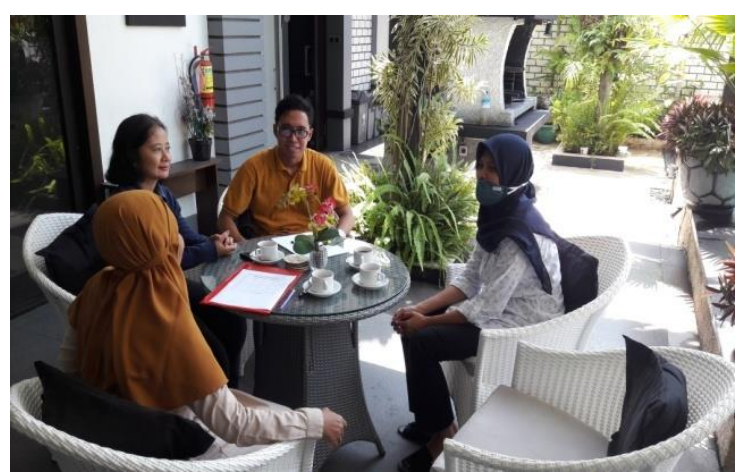

Gambar 2. Kegiatan Pelatihan Kepada Pihak Manajemen Hotel (Sumber: Data Penulis).

\section{SIMPULAN DAN SARAN Simpulan}

Setelah diberikan penyuluhan dan pelatihan, manajemen RPA Batu layar Senggigi mengakui mereka memiliki kemampuan dan keterampilan yang memadai dalam membuat pencatatan yang digunakan untuk menghitung harga pokok produksi. Manajemen RPA dapat dengan mudah menentukan harga jual dengan menggunakan pendekatan ful cost, sehingga dapat menentukan harga jual setelah ditambah dengan margin yang diinginkan dari harga pokok kamar, sehingga laba secara periodik suatu perusahaan dapat diprediksi dengan baik.

\section{Saran}

Pelatihan perhitungan harga pokok dengan menggunakan excel ini diharapkan dapat diterapkan di hotel rumah putih abu-abu di dalam pengambilan keputusan penetapan harga jual kamar dan digunakan untuk mengestimasi laba yang diperoleh hotel.

\section{UCAPAN TERIMAKASIH}

Pelaksanaan kegiatan Pengabdian Kepada Masyarakat ini telah melibatkan berbagai pihak, oleh karena itu pada kesempatan ini kami mengucapkan terima kasih dan penghargaan kepada :

1 LPPM UNRAM selaku koordinator pelaksanaan pengabdian kepada masyarakat.

2 Fakultas Ekonomi dan Bisnis Universitas Mataram dan BP2EB Fakultas Ekonomi dan Bisnis Universitas Mataram.

3 Manajemen Hotel RPA Batu Layar Senggigi yang telah memberikan ijin dan berpartisipasi dalam pelaksanaan kegiatan pengabdian.

\section{DAFTAR RUJUKAN}

David, R. J., llat, V., \& Morasa, J. (2020). Perhitungan tarif kamar hotel menggunakan activity based costing pada Hotel Sapadia Kotamobagu. 
Indonesia Accounting Journal, 2(2), 103. https://doi.org/10.32400/iaj.27798

Hermawan, H., Bramanto, E., \& Hamzah, F. (2018). Pengantar Manajemen Hospitality. Jawa Tengah: PT Nasya Expanding Management.

Isdarmanto. (2017). Dasar-Dasar Kepariwisataan dan Pengelolaan Destinasi Wisata. Yogyakarta: Sekolah Tinggi Pariwisata Amburakmo.

Kaukab, M. E. (2019). Implementasi ActivityBased Costing Pada UMKM. Journal of Economic, Management, Accounting and Technology, 2(1), 69-78. https://doi.org/10.32500/jematech.v2i1. 576

Mulyadi. (2014). Akuntansi Biaya (Edisi Keli). Yogyakarta: Sekolah Tinggi IImu Manajemen YKPN.

Sujarweni, V. W. (2017). Implementasi Penentuan Harga Pokok Produksi Untuk Mencapai Laba Optimal (Studi Pada Sentra Ukm Industri Bakpia Di Wilayah Minomartani Sleman Yogyakarta). Jurnal Riset Akuntansi dan Keuangan, 4(3), 1111-1124. https://doi.org/10.17509/jrak.v4i3.4665

Yuniari, N. K., Wahyuni, M. A., \& Dewi, P. E. D. M. (2017). Analisis Ketetapan Perhitungan Harga Pokok Produksi Berdasarkan Metode Full Costing Sebagai Dasar Dalam Menentukan Harga Jual Ukiran Sanggah (Pelinggih) Pada Usaha Sari uma Dukuh Sidemen. e-Journal S1 Ak, 8(2), 1-10. Diambil dari https://ejournal.undiksha. ac.id/index.php/S1ak/article/view/1316 4 